American J. of Engineering and Applied Sciences 3 (4): 588-596, 2010

ISSN 1941-7020

(C) 2010 Science Publications

\title{
Performance Evaluation of a Heavy Duty Chisel Plow at Various Tillage Depth and Forward Speeds
}

\author{
S.A. Al-Suhaibani and A.E. Ghaly \\ Department of Agricultural Engineering, College of Food Science and Agriculture, \\ King Saud University, P.O. Box 2460, Riyadh 11451, Kingdom of Saudi Arabia
}

\begin{abstract}
Problem statement: Tillage is a process of creating a desirable soil condition for seed germination and growth. The tillage of soil is considered to be one of the biggest farm operations as the tillage operation requires the most energy on the farm. Manufacturers of tillage implements tend to overdesign their products due to a lack of the proper testing and analysis of tillage tools and the technical expertise required to optimize the farm operations. Chisel plow is widely used by farmers as a primary tillage tool. Performance data for chisel plow operation is essential in order to optimize its performance and reduce the cost of tillage operation. Approach: Field experiments were conducted using a fully instrumented MS 3090 tractor to evaluate the performance of a heavy duty chisel plow in a sandy soil over wide ranges of plowing depths and forward speeds. The plowing depth, forward speed and draft were measured and recorded using an instrumentation system and data logger. Results: The effects of plowing depth and forward speeds on draft, unit draft, vertical specific draft, horizontal specific draft and coefficient of pull were evaluated. The results indicated that increasing the plowing depth and/or the forward speed increased the draft, unit draft and vertical specific draft. Also, increasing the plowing depth increased the horizontal specific draft and the coefficient of pull, while increasing the forward speed decreased the horizontal specific draft and the coefficient of pull. Conclusion: About $26.7 \%$ of the draft force was directed towards cutting the soil and $73.3 \%$ was consumed in pulverization of soil particles. The values of the vertical specific draft were much higher than those of the horizontal specific draft for all plowing depths and forward speeds. The plowing depth had more pronounced effect on the draft, unit draft, specific draft and coefficient of pull than the forward speed. The optimum forward speed was $1.75 \mathrm{~m} \mathrm{sec}^{-1}$. The recommended plowing depth should be based on the type of crop (depth of the root system).
\end{abstract}

Key words: Tillage, draft, unit draft, specific draft, coefficient of pull, sandy soil, instrumentation, chisel plow

\section{INTRODUCTION}

Tillage is defined as a process aimed at creating a desired final soil condition for seeds from some undesirable initial soil condition through manipulation of soil with the purpose of increasing crop yield (Gill and Vanden Berg, 1967). The selection of tillage implements for seedbed preparation and weed control depends on soil type and condition, type of crop, previous soil treatments, crop residues and weed type (Raper, 2002). One of the tillage implements widely used by farmers is the chisel plow which is considered to be a primary tillage implement because it is mainly used for the initial soil working operations. Chisel plows function most effectively when the soil is dry and firm (Srivastava, 1993).
The tillage of soil is considered to be one of the biggest farm operations as it requires the most energy spent on farms (Finner and Straub, 1985; AbbaspurGilandeh et al., 2006). Therefore, draft power requirements are important in order to determine the size of the tractor that could be used for a specific implement. The draft required for a given implement will also be affected by the soil conditions and the geometry of the tillage implement (Taniguchi et al., 1999; Naderloo et al., 2009; Olatunji and Donis, 2009).

The effect of soil conditions, tillage depth and forward speed on soil translocation by chisel plow was studied by Van Muysen et al. (2000). They defined the specific draft as force per cross sectional area of worked soil. Arvidsson et al. (2004) found the specific draft of the chisel plow to be higher than those of the

Corresponding Author: S.A. Al-Suhaibani, Department of Agricultural Engineering, College of Food Science and Agriculture, King Saud University, P.O. Box 2460, Riyadh 11451, Kingdom of Saudi Arabia 
moldboard plow and the disc harrow and referred that to the differences in implement geometry and mode of soil break-up.

Owen (1989) studied the force-depth relationship of a chisel plow tine with three different wing types in a compacted clay loam soil and found the vertical force on the tine to increase linearly with the operating depth while the horizontal force, moment and total force to increase quadratic ally with operating depth. He also noticed that the wing width had a significant effect on the vertical force and no interaction existed between the wing width and the depth.

Several models were developed to predict draft for tillage tools based on soil condition, soil properties and implement width (Sahu and Raheman, 2006). Mamman and Qui (2005) studied the draft performance of a model chisel plow using a soil bin. The design parameters considered were: the nose angle, the slide angle, the depth and the forward speed. The draft increased with increases in tillage depth, the nose and slide angles and the cutting edge height.

Gill and Vanden Berg (1967) stated that the efficiency and economy of the tillage operation could be evaluated from the mechanics of tillage tools/soil interaction which would provide a method by which the performance of the tillage implements could be predicted and controlled by the design of a tillage tool or by the use of a sequence of tillage tools.

In studying the strength and forces for the chisel plow, Brown et al. (1989) evaluated the stress on the chisel plow using the finite element analysis and reduced the weight by $23 \%$ without causing excessive stress on the plow.

Brown et al. (1989) stated that manufacturers of tillage implements tend to overdesign their products due to a lack of the proper design and analysis of tillage tools and the technical expertise required to optimize the strength of an implement. The main objectives of this study was to evaluate the performance of a heavy duty $(415 \mathrm{~kg}$ or $3.73 \mathrm{kN})$ chisel plow with 15 shanks distributed in two rows in a sandy soil. The specific objectives were to study the effects of plowing depth and forward speed on: (a) draft, (b) unit draft, (c) specific draft and (d) coefficient of pull.

\section{MTERIALS AND METHODS}

Tractors and instrumentation system: A fully instrumented Massy Ferguson (MF 3090) tractor (Fig. 1) was used in the study. The specification of the tractor is presented in Table 1. The instrumentation system consisted of: (a) a drawbar dynamometer, to measure drawbar pull (b) two wheel torque transducers, to measure wheel forces (c) a three-point linkageimplement force and depth transducer, to measure the three-point linkage forces and depth, (d) other transducers, to monitor ground speed, fluid temperatures (engine oil, transmission oil, front axle oil, engine coolant and engine fuel), Power Take Off (PTO) torque, right and left positions of front wheel steering and angular position and indication of the lifting position of the three-point linkage, (e) a data logger, to monitor and record data from various parameters and (f) a computer, for processing and analyzing data (AlSuhaibani et al., 2010).

Figure 2 shows the draft, forward speed and depth measuring devices of the instrumentation system. The draft was measured using a drawbar dynamometer consisting of two load sensing clevis bolts and the force exerted by the plow was measured by a strain gauge bridge within the clevis bolts. The tractor ground speed was measured using a fifth wheel attached to a suitable position underneath the tractor. An RS shaft encoder (360 pulses/revolution) was mounted on the fifth wheel and used to measure the distance traveled and hence the actual ground speed. The depth was measured using the three point linkage-implement force and depth transducer which was developed specifically for use with mounted implement of categories II (40-100 hp) and III (80-225 hp) as specified by the ASAE Standards (1985).

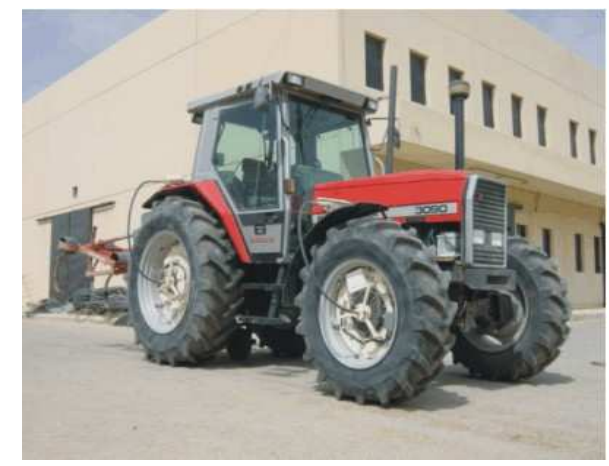

Fig. 1: The MS 3090 fully instrumented tractor

Table 1: Tractor specifications

\begin{tabular}{lc}
\hline Parameter & Value \\
\hline Power & $75.00 \mathrm{~kW}$ \\
Weight & $47.35 \mathrm{kN}$ \\
Weight on front wheels & $18.50 \mathrm{kN}$ \\
Weight on rear wheels & $28.85 \mathrm{kN}$ \\
Distance between front and rear wheels & $269.90 \mathrm{~cm}$ \\
Distance between front wheels & $187.00 \mathrm{~cm}$ \\
Distance between rear wheels & $163.00 \mathrm{~cm}$ \\
Front wheels size & $31.60 \mathrm{R} 28$ \\
Rear wheels size & $18.40 \mathrm{R} 38$ \\
Height of drawbar & $58.30 \mathrm{~cm}$ \\
Height of center of gravity & $174.00 \mathrm{~cm}$ \\
\hline
\end{tabular}




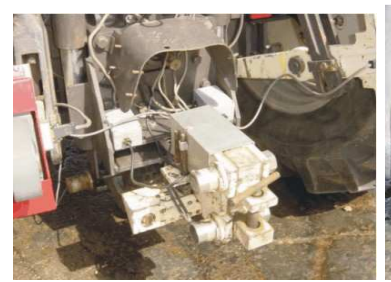

(a)

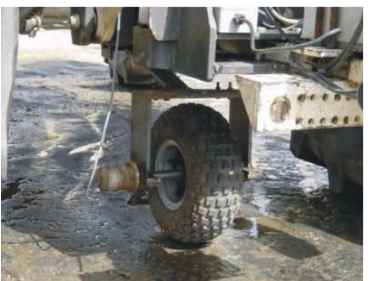

(b)

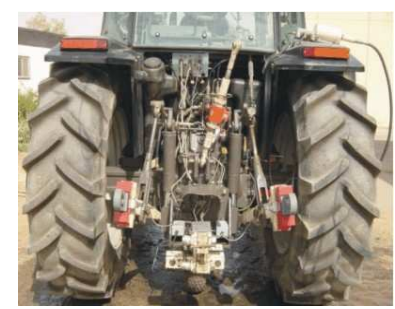

(c)

Fig. 2: Draft, speed and depth measuring devices. (a) draw bar dynamometer; (b) The fifth wheel; (c) The three point linkage and tillage depth device

\begin{tabular}{|c|c|c|c|}
\hline \multicolumn{4}{|l|}{ ic:MresultiT est 1} \\
\hline Rear Rolling Radius & $:(\mathrm{m})$ & 0.833654 & \\
\hline Front Rolling Radius & $:(\mathrm{m})$ & 0.635000 & \\
\hline 5th Rolling Radius & $:(\mathrm{m})$ & 0.178136 & \\
\hline Lift link & $:(\mathrm{mm})$ & 790.00000 & \\
\hline Mast Height & $:(\mathrm{mm})$ & 690.00000 & \\
\hline Top Link & $:(\mathrm{mm})$ & 760.00000 & \\
\hline Implement Width & $:(\mathrm{m})$ & 2.000000 & \\
\hline Implement Width & $:(\mathrm{kg})$ & 250.00000 & \\
\hline Cancel & $\gg \mathrm{BaC}$ & & Next $\gg$ \\
\hline
\end{tabular}

Fig. 3: A laptop screen showing data

A data logger mounted on a platform to the left of the tractor operator was used to scan and record the output signals from the transducers. The strain gauge transducers in the instrumentation system were connected to the data logger through amplifier boxes, which also provided a regulated power supply to give excitation to the transducer. The activity unit was used to provide excitation to both the data logger and transducers with input supply from the tractor battery $(12 \mathrm{~V})$. It was, also, used to indicate the activity performed during field tests. The data was displayed on a laptop as shown in Fig. 3.

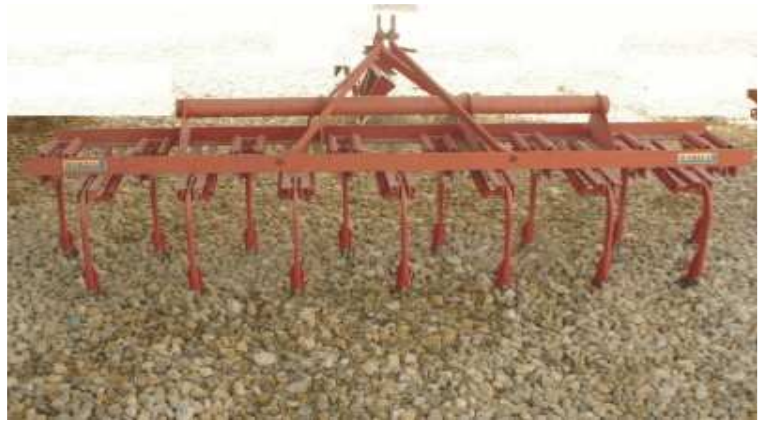

Fig. 4: The heavy duty chisel plow

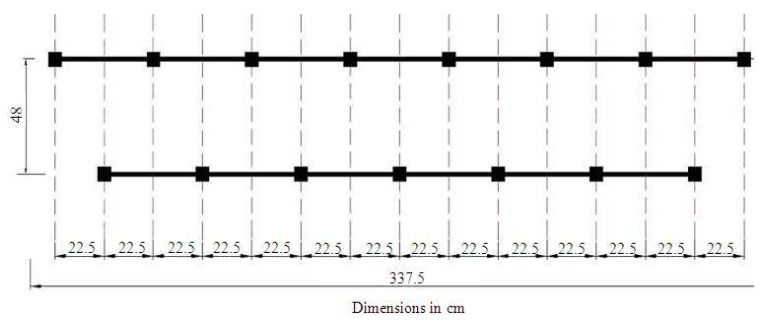

Fig. 5: Distribution of shanks on the plow frame. Plow width $=315 \mathrm{~cm}$; With of plowed strip $=337.5$ $\mathrm{cm}$; Distance between the paths of shanks = $22.5 \mathrm{~cm}$

Table 2: Chisel plow specifications

\begin{tabular}{ll}
\hline Parameter & Volume \\
\hline Type of plow & Heavy duty \\
Model & CMP/15-R. (Serial \\
& No. 59062) \\
Manufacture & MARZIA \\
& Company Italy \\
Total weight & $415 \mathrm{~kg}(4.07 \mathrm{kN})$ \\
Total width of tillage & $337.5 \mathrm{~cm}$ \\
Number of shanks & 15 \\
Width of shank & $5 \mathrm{~cm}$ \\
Thickness of shank & $2.5 \mathrm{~cm}$ \\
Shank stem angle & $51^{\circ}$ \\
Number of rows & 2 \\
Number of shanks in first row & 8 \\
Distance between shanks in first row & $45 \mathrm{~cm}$ \\
Number of shanks in second row & 7 \\
Distance between shanks in second row & $45 \mathrm{~cm}$ \\
Width of chisel tool & $6 \mathrm{~cm}$ \\
\hline
\end{tabular}

Chisel plow: A heavy duty (chisel plow (Model CMP/15-R, Serial No. 59062, Marzia, Italy) was used in the study. The plow (Fig. 4) weighed $415 \mathrm{~kg}$ (4.07 $\mathrm{kN}$ ) and had a width of $315 \mathrm{~cm}$.

It had 15 shanks distributed in 2 rows. The specifications of the plow are shown in Table 2. Figure 6 shows the distribution of shanks on plow frame while Fig. 7 shows the distance between the paths of shanks and the width of worked soil (plowed strip). 
Am. J. Engg. \& Applied Sci., 3 (4): 588-596, 2010

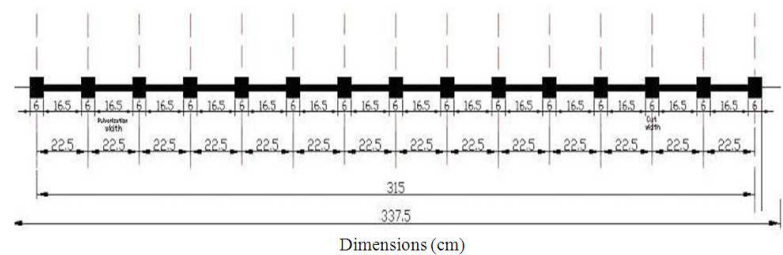

Fig. 6: Distance between the paths of shanks. Width of plowed strip $=337.5 \mathrm{~cm}$; Number of shanks $=15$; Width of chisel tool $=6 \mathrm{~cm}$; Total width cut $=90$ $\mathrm{cm} ; \%$ of cut $=26.7 \%$; Width of pulverization $=247.5 \mathrm{~cm} ; \%$ of pulverization $=73.3 \%$

Table 3: Experimental parameters

\begin{tabular}{ll}
\hline Parameter & Values \\
\hline Depth $(\mathrm{mm})$ & $115,160,230$ \\
Speed $\left(\mathrm{m} \mathrm{sec}^{-1}\right)$ & $0.75,1.20,1.75,2.30$ \\
\hline
\end{tabular}

Field experiments: Experiments were conducted using the fully instrumented MF 3090 tractor to measure the draft requirement of a heavy duty chisel plow in a sandy loam soil over wide ranges of forward speeds and tillage depths at the Agricultural Research and Experimental Farm of the King Saud University in Dirab. Four speeds and three depths were tested as shown in Table 3. This resulted in 12 treatment combinations. Ten measurements were taken for each treatment combinations at $5 \mathrm{~min}$ intervals. The data logger monitored and recorded the data for the tillage depth, forward speed and draft during the field experiment. The laptop displayed the values of the measured parameters and analyzed the data.

\section{RESULTS}

The width of the plow was $315 \mathrm{~cm}$ and the width of plowed strip was $337.5 \mathrm{~cm}$. The total width of cut $(90$ $\mathrm{cm})$ was calculated by multiplying the width of cutting tool $(6 \mathrm{~cm})$ by the number of shanks $(15)$. The remaining part of the width of plowed strip $(247.5 \mathrm{~cm})$ was considered to be the width of pulverization. Accordingly, the plow cutting tool were able to cut $26.7 \%$ of the total plowed width and the movement of the soil (pulverization) resulted in the breakage of soil particles and preparation of the seedbed. Table 4 shows the measured draft force $(\mathrm{kN})$ and the calculated unit draft $\left(\mathrm{kN} \mathrm{m}^{-1}\right)$ at various plowing depths and forward speeds. The unit draft is defined in this study as the draft per unit width of the worked soil (plowed strip).

Table 5 shows the calculated vertical specific draft $\left(\mathrm{Kn} \mathrm{m}^{-2}\right)$ which is defined in this study as the draft per projected vertical unit area of cut (vertical cross sectional area of worked soil). The vertical cross sectional area of the worked soil was calculated by multiplying the plowing depth by the width of plowed strip.
Table 4: Draft and unit draft

\begin{tabular}{llll}
\hline $\begin{array}{l}\text { Depth } \\
(\mathrm{mm})\end{array}$ & $\begin{array}{l}\text { Speed } \\
\left(\mathrm{m} \mathrm{sec}^{-1}\right)\end{array}$ & $\begin{array}{l}\text { Draft } \\
(\mathrm{kN})\end{array}$ & $\begin{array}{l}\text { Unit Draft } \\
\left(\mathrm{kN} \mathrm{m}^{-1}\right)\end{array}$ \\
\hline 115 & 0.75 & $3.01(0.235)$ & 0.89 \\
& 1.20 & $3.61(0.172)$ & 1.07 \\
& 1.75 & $3.74(0.161)$ & 1.11 \\
160 & 2.30 & $4.37(0.264)$ & 1.29 \\
& 0.75 & $5.38(0.338)$ & 1.59 \\
& 1.20 & $6.44(0.279)$ & 1.91 \\
& 1.75 & $7.11(0.221)$ & 2.11 \\
230 & 2.30 & $7.85(0.296)$ & 2.33 \\
& 0.75 & $8.19(0.146)$ & 2.43 \\
& 1.20 & $9.47(0.178)$ & 2.81 \\
& 1.75 & $10.31(0.754)$ & 3.05 \\
& 2.30 & $11.53(0.427)$ & 3.42 \\
\hline
\end{tabular}

( ) The values represent standard deviation; Plow width $=315 \mathrm{~cm}$; Width of plowed strip $=337.5 \mathrm{~cm}$; Unit draft $=$ draft $/$ width of plowed strip

Table 5: Vertical specific draft 5

\begin{tabular}{lllrll}
\hline & & \multicolumn{3}{c}{ Vertical specific draft $\left(\mathrm{kN} \mathrm{m}^{-2}\right)$} \\
& $\begin{array}{l}\text { Speed } \\
\left(\mathrm{m} \mathrm{sec}^{-1}\right)\end{array}$ & $\begin{array}{l}\text { Draft } \\
(\mathrm{kN})\end{array}$ & \multicolumn{1}{c}{ Total } & Cutting & Pulverization \\
\hline 115 & 0.75 & 3.01 & 7.76 & 2.07 & 5.69 \\
& 1.20 & 3.61 & 9.30 & 2.48 & 6.82 \\
& 1.75 & 3.74 & 9.64 & 2.57 & 7.07 \\
& 2.30 & 4.37 & 11.26 & 3.00 & 8.26 \\
160 & 0.75 & 5.38 & 9.96 & 2.66 & 7.31 \\
& 1.20 & 6.44 & 11.93 & 3.18 & 8.75 \\
& 1.75 & 7.11 & 13.17 & 3.51 & 9.66 \\
& 2.30 & 7.85 & 14.54 & 3.88 & 10.66 \\
& 0.75 & 8.19 & 10.55 & 2.81 & 7.74 \\
& 1.20 & 9.47 & 12.20 & 3.25 & 8.95 \\
& 1.75 & 10.31 & 13.29 & 3.55 & 9.74 \\
& 2.30 & 11.53 & 14.86 & 3.97 & 10.89 \\
\hline
\end{tabular}

Vertical tilled area $=$ Depth of tillage $\times$ width of plowed strip; For a depth of $115 \mathrm{~mm}=0.115 \times 3.375=0.388 \mathrm{~m}^{2}$; For a depth $160 \mathrm{~mm}=$ $0.160 \times 3.375=0.540 \mathrm{~m}^{2} ;$ For a depth $230 \mathrm{~mm}=0.230 \times 2.1=0.776$ $\mathrm{m}^{2} ; \%$ Width of Plow Strip $=26.7 \%$

Table 6: Horizontal specific draft

\begin{tabular}{llllll}
\hline $\begin{array}{l}\text { Depth } \\
(\mathrm{mm})\end{array}$ & $\begin{array}{l}\text { Speed } \\
\left(\mathrm{m} \mathrm{sec}^{-1}\right)\end{array}$ & $\begin{array}{c}\text { Draft } \\
(\mathrm{kN})\end{array}$ & $\begin{array}{l}\text { Horizontal vertical specific draft }\left(\mathrm{kN} \mathrm{m}^{-2}\right) \\
\text { Total }\end{array}$ & Cutting & Pulverization \\
\hline 115 & 0.75 & 3.01 & 1.19 & 0.32 & 0.87 \\
& 1.20 & 3.61 & 0.89 & 0.24 & 0.65 \\
& 1.75 & 3.74 & 0.63 & 0.17 & 0.46 \\
& 2.30 & 4.37 & 0.56 & 0.15 & 0.41 \\
160 & 0.75 & 5.38 & 2.13 & 0.57 & 1.56 \\
& 1.20 & 6.44 & 1.59 & 0.42 & 1.17 \\
& 1.75 & 7.11 & 1.20 & 0.32 & 0.88 \\
230 & 2.30 & 7.85 & 1.01 & 0.27 & 0.74 \\
& 0.75 & 8.19 & 3.24 & 0.86 & 2.37 \\
& 1.20 & 9.47 & 2.34 & 0.62 & 1.71 \\
& 1.75 & 10.31 & 1.91 & 0.51 & 1.40 \\
& 2.30 & 11.53 & 1.49 & 0.40 & 1.09
\end{tabular}

Horizontal tilled area $=$ Width of plowed strip $\times$ forward speed; Width of plow strip $=337.5 \mathrm{~cm}$

The portions of vertical specific draft used for cutting the soil and moving the soil particles (pulverization) were also calculated as shown in Table 5 . 
Am. J. Engg. \& Applied Sci., 3 (4): 588-596, 2010

Table 6 shows the calculated horizontal specific draft which is defined in this study as the draft divided by horizontal plowed area per unit time (second). The horizontal plowed area per unit time was calculated by multiplying the forward speed by the width of plowed strip. The percentage of horizontal specific draft used for cutting and moving soil particles (pulverization) were calculated as shown in Table 6 .

Table 7 shows the total weight of the plow and the worked soil (cut/moved by the plow) at various plowing depths and forward speeds. The weight of worked soil was calculated from the volume of soil created by the plowing depth, the forward movement of the plow in a unit time (second) and the width of plowed strip. The coefficient of pull $\left(\mathrm{kN} \mathrm{kN}^{-1}\right)$ was calculated by dividing the draft by the total weight of plow and the worked soil. The results are also presented in Table 7.
Table 7: Coefficient of pull

\begin{tabular}{|c|c|c|c|c|c|}
\hline $\begin{array}{l}\text { Depth } \\
(\mathrm{mm})\end{array}$ & $\begin{array}{l}\text { Speed } \\
\left(\mathrm{m} \mathrm{sec}^{-1}\right)\end{array}$ & $\begin{array}{l}\text { Draft } \\
(\mathrm{kN})\end{array}$ & $\begin{array}{l}\text { Volume of } \\
\text { worked } \\
\text { soil }\left(\mathrm{m}^{3}\right)\end{array}$ & $\begin{array}{l}\text { Weigh of } \\
\text { plow and } \\
\text { worked } \\
\text { soil }(\mathrm{kN})\end{array}$ & $\begin{array}{l}\text { Coefficient } \\
\text { of pull } \\
\left(\mathrm{kN} \mathrm{kN}^{-1}\right)\end{array}$ \\
\hline \multirow[t]{4}{*}{115} & 0.75 & 3.01 & 0.29 & 7.93 & 0.38 \\
\hline & 1.20 & 3.61 & 0.47 & 10.24 & 0.35 \\
\hline & 1.75 & 3.74 & 0.68 & 13.07 & 0.29 \\
\hline & 2.30 & 4.37 & 0.89 & 15.89 & 0.27 \\
\hline \multirow[t]{4}{*}{160} & 0.75 & 5.38 & 0.41 & 9.43 & 0.57 \\
\hline & 1.20 & 6.44 & 0.65 & 12.65 & 0.51 \\
\hline & 1.75 & 7.11 & 0.95 & 16.59 & 0.43 \\
\hline & 2.30 & 7.85 & 1.24 & 20.52 & 0.38 \\
\hline \multirow[t]{4}{*}{230} & 0.75 & 8.19 & 0.58 & 11.78 & 0.69 \\
\hline & 1.20 & 9.47 & 0.93 & 16.40 & 0.58 \\
\hline & 1.75 & 10.31 & 1.36 & 22.06 & 0.47 \\
\hline & 2.30 & 11.53 & 1.79 & 27.71 & 0.41 \\
\hline
\end{tabular}

Plow Weight $=415 \mathrm{~kg}=4.07 \mathrm{kN}$; Volume of worked soil $=$ Plowed depth $\times$ width of plowed strip $\times$ forward speed; Soil density $=1350 \mathrm{~kg}$ $\mathrm{m}^{-3}=13.24 \mathrm{kN} \mathrm{m}^{-3}$

Table 8: The rate of incremental increase in various kinetic parameters with increases in forward speed at various depths

\begin{tabular}{|c|c|c|c|c|c|}
\hline \multirow[b]{2}{*}{ Depth (mm) } & \multirow[b]{2}{*}{ Speed interval $\left(\mathrm{m} \mathrm{sec}^{-1}\right)$} & \multicolumn{4}{|c|}{ Increase in parameters } \\
\hline & & $\mathrm{D}\left(\mathrm{kN} \mathrm{m}^{-1} \mathrm{sec}^{-1}\right)$ & $\mathrm{V}\left(\mathrm{kN} \mathrm{m} \mathrm{m}^{-2} \mathrm{~m}^{-1} \mathrm{sec}^{-1}\right)$ & $\mathrm{H}\left(\mathrm{kN} \mathrm{m}^{-1} \mathrm{sec}^{-1}\right)$ & $\mathrm{C}\left(\mathrm{kN} \mathrm{kN}^{-1} \mathrm{~m}^{-1} \mathrm{sec}^{-1}\right)$ \\
\hline \multirow[t]{3}{*}{115} & $0.75-1.20$ & 1.33 & 3.42 & 0.67 & 0.07 \\
\hline & $1.20-1.75$ & 0.24 & 0.62 & 0.47 & 0.11 \\
\hline & $1.75-2.30$ & 1.45 & 2.95 & 0.13 & 0.04 \\
\hline \multirow[t]{3}{*}{160} & $0.75-1.20$ & 2.36 & 4.38 & 1.20 & 0.13 \\
\hline & $1.20-1.75$ & 1.22 & 2.25 & 0.71 & 0.15 \\
\hline & $1.75-2.30$ & 1.35 & 2.49 & 0.36 & 0.09 \\
\hline \multirow[t]{3}{*}{230} & $0.75-1.20$ & 2.84 & 3.67 & 2.00 & 0.24 \\
\hline & $1.20-1.75$ & 1.89 & 1.98 & 0.78 & 0.20 \\
\hline & $1.75-2.30$ & 1.49 & 2.85 & 0.76 & 0.09 \\
\hline
\end{tabular}

D: Draft; V: Vertical specific draft; H: Horizontal specific draft; C: Coefficient of pull

Table 9: The rate pf incremental increase in various kinetic parameters with increases in forward speed at various speeds

\begin{tabular}{|c|c|c|c|c|c|}
\hline \multirow[b]{2}{*}{ Speed $\left(\mathrm{m} \mathrm{sec}^{-1}\right)$} & \multirow[b]{2}{*}{ Depth intervals $(\mathrm{mm})$} & \multicolumn{4}{|l|}{ Changes in draft } \\
\hline & & $\mathrm{D}\left(\mathrm{kN} \mathrm{m}^{-1} \mathrm{sec}^{-1}\right)$ & $\mathrm{V}\left(\mathrm{kN} \mathrm{m}^{-2} \mathrm{~m}^{-1} \mathrm{sec}^{-1}\right)$ & $\mathrm{H}\left(\mathrm{kN} \mathrm{m}^{-1} \mathrm{sec}^{-1}\right)$ & $\mathrm{C}\left(\mathrm{kN} \mathrm{kN}^{-1} \mathrm{~m}^{-1} \mathrm{sec}^{-1}\right)$ \\
\hline \multirow[t]{2}{*}{0.75} & $115-160$ & 52.67 & 48.89 & 20.88 & 4.22 \\
\hline & $160-230$ & 40.14 & 8.42 & 15.85 & 1.71 \\
\hline \multirow[t]{2}{*}{1.2} & $115-160$ & 62.89 & 5.84 & 15.55 & 3.56 \\
\hline & $160-230$ & 43.29 & 3.85 & 10.71 & 1.00 \\
\hline \multirow[t]{2}{*}{1.75} & $115-160$ & 74.89 & 78.44 & 12.67 & 3.11 \\
\hline & $160-230$ & 48.57 & 1.71 & 10.14 & 0.57 \\
\hline \multirow[t]{2}{*}{2.3} & $115-160$ & 77.33 & 27.89 & 10.00 & 2.44 \\
\hline & $160-230$ & 49.71 & 4.57 & 6.85 & 0.87 \\
\hline
\end{tabular}

D: Draft; V: Vertical specific draft; H: Horizontal specific draft; C: Coefficient of pull

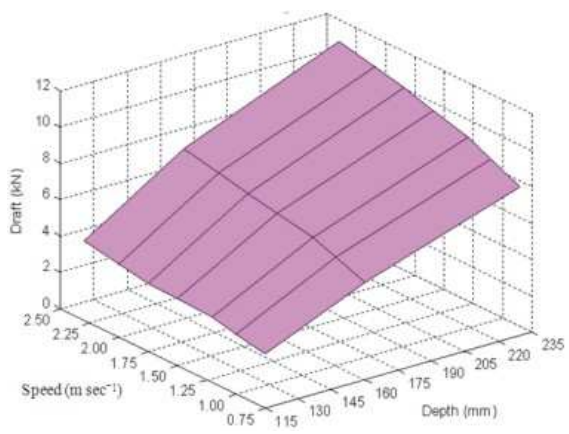

(a)

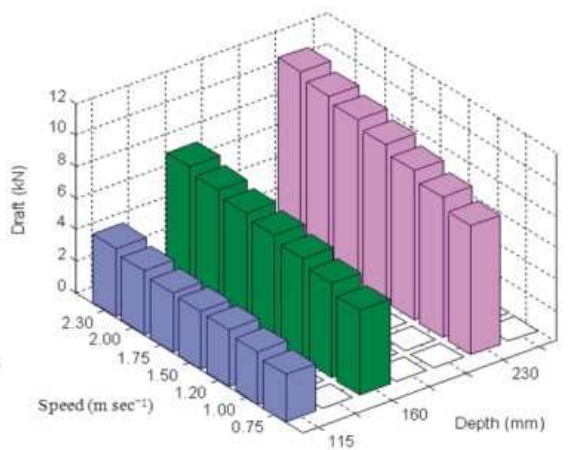

(b)

Fig. 7: Effects of plowing depth and forward speed on the measured draft 


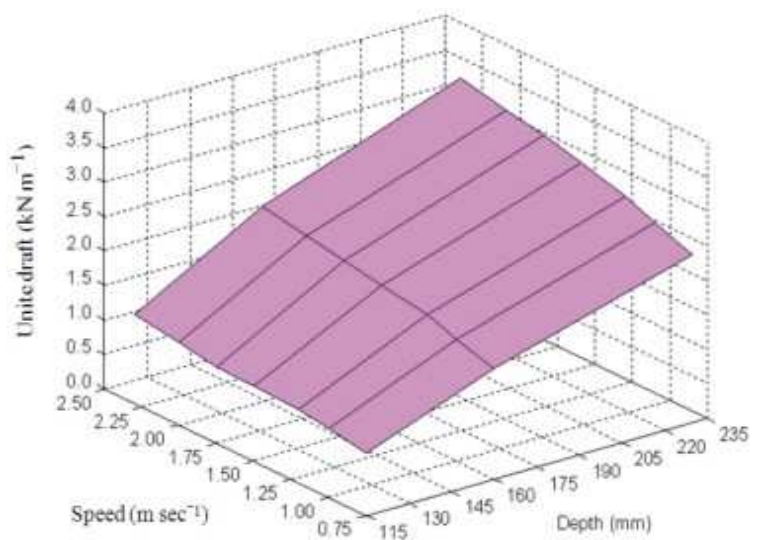

(a)

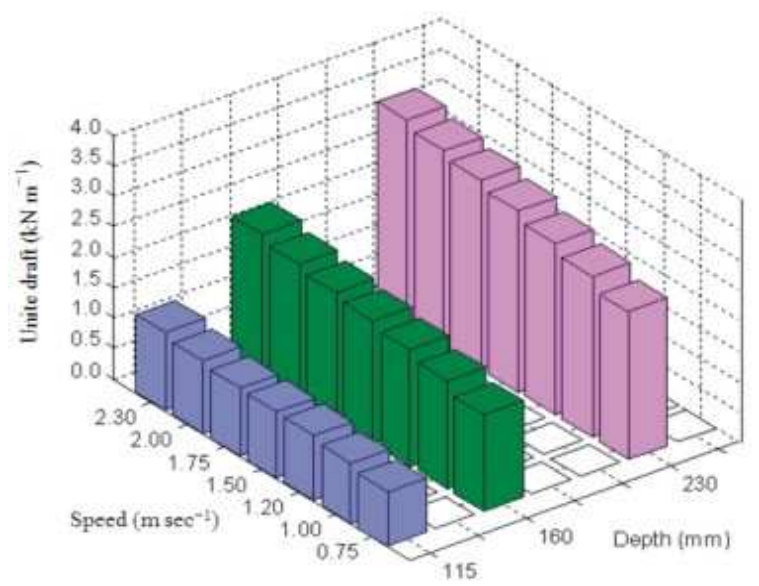

(b)

Fig. 8: Effects of plowing depth and forward speed on the unit draft

Figure 7-11 show the effects of plowing depth and forward speed on the draft, unit draft, vertical specific draft, horizontal specific draft and coefficient of pull.

Draft and unit draft: The force required to work (cut and move) the soil varied with both the plowing depth and the forward speed as shown in Table 4. However, the increase in draft with the plowing depth or the forward speed did not appear to be linear as shown in Fig. 7. For all plowing depths, the observed rate of increase in draft when the forward speed was increased from $0.75-1.20 \mathrm{~m} \mathrm{sec}^{-1}$ was higher than the observed rate of increases in the draft when the forward speed was increased from 1.20-1.75 $\mathrm{m} \mathrm{sec}^{-1}$ and from $1.75-2.30 \mathrm{~m}$ $\mathrm{sec}^{-1}$ as shown in Table 8 . However, the rate of increase in the draft observed when the forward speed was increased from 1.20-1.75 m sec $\mathrm{mas}^{-1}$ lower than the observed rate of increase in the draft observed when the forward speed was increased from $1.75-2.30 \mathrm{~m} \mathrm{sec}^{-1}$.

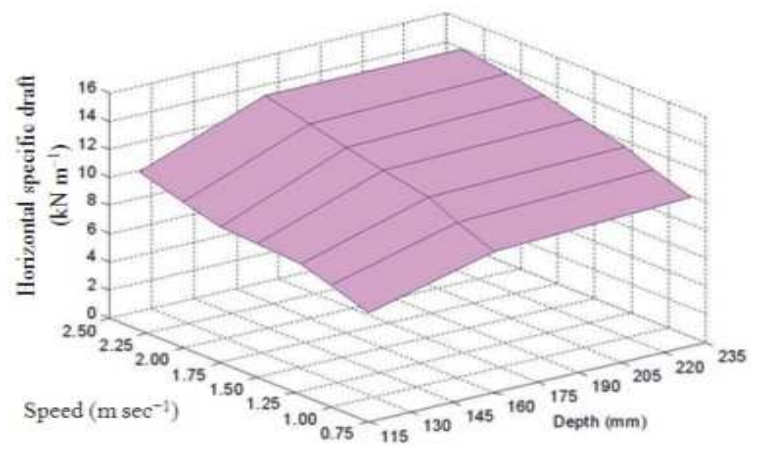

(a)

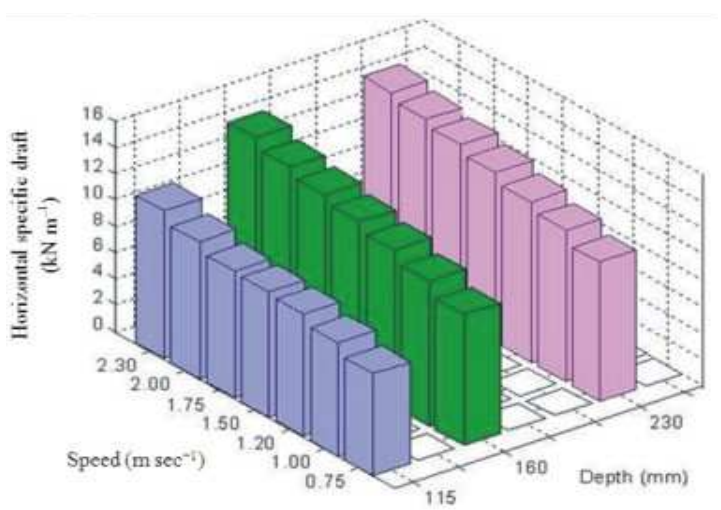

(b)

Fig. 9: Effects of plowing depth and forward speed on the horizontal specific draft

This may indicate that the forward speed of $1.75 \mathrm{~m}$ $\mathrm{sec}^{-1}$ is the optimum speed. It was, also, observed that the rate of increase in draft when the depth was increased from 115-160 $\mathrm{mm}$ was higher than the rate of increase in the draft when the depth was increased from 160-230 $\mathrm{mm}$ as shown in Table 9.

The unit draft was defined in this study as the draft divided by the width of worked soil (width of plowed strip). The results followed the same trend as the draft as shown in Table 4 and Fig. 8. It appears, also, that the plowing depth had more effect on the unit draft than the forward speed. Increasing the depth from 115-230 mm (100\%) increased the unit draft by $172.1,162.3175 .6$ and $163.8 \%$ for the forward speeds of $0.75,1.20,1.75$ and $2.30 \mathrm{~m} \mathrm{sec}^{-1}$, respectively. On the other hand, increasing the forward speed from $0.75-2.30 \mathrm{~m} \mathrm{sec}^{-1}$ $(206.6 \%)$ increased the unit draft by $45.2,45.9$ and $40.8 \%$ for the plowing depths of 115,160 and $230 \mathrm{~mm}$, respectively. On the average, doubling the plowing depth increased the unit draft by about $168.3 \%$ while doubling the forward speed increased the unit draft by $21.3 \%$. 


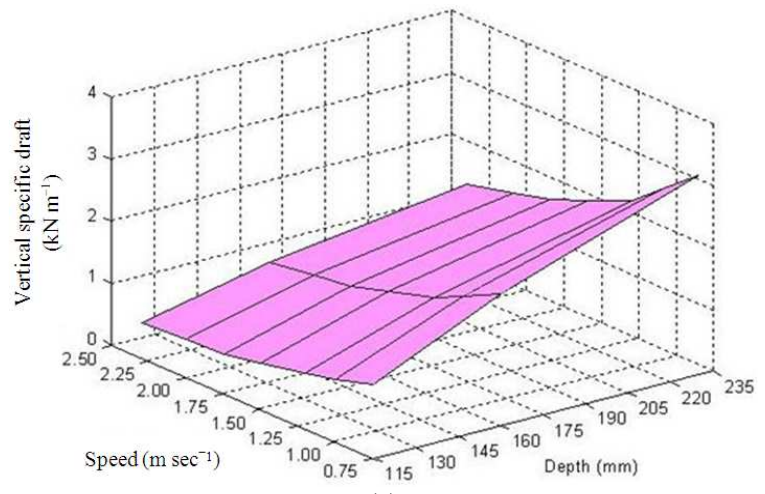

(a)

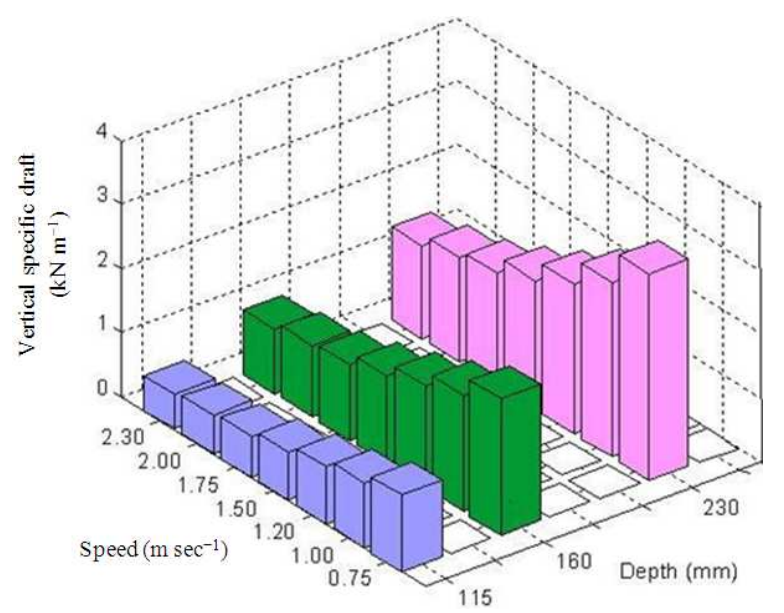

(b)

Fig. 10: Effects of plowing depth and forward speed on the vertical specific draft

Table 10: Seeding depth and root length of common agricultural crops

\begin{tabular}{lll}
\hline Crop & Seeding depth $(\mathrm{mm})$ & Root length $(\mathrm{cm})$ \\
\hline Egg plant & 20 & $50-60$ \\
Clover & 50 & $40-50$ \\
Corn & 50 & $30-40$ \\
Fava beans & 25 & $30-40$ \\
Wheat (all cereals) & 25 & $30-40$ \\
Cucumber & 20 & 40 \\
Beans & 20 & 30 \\
Tomatoes & 20 & 25 \\
Lutes & 20 & 20
\end{tabular}

Similar results were reported in the literature. Mamman and Qui (2005) studied the performance of a chisel plow and found the speed and tillage depth to have more influence on the draft than the plow design. Sahu and Roheman (2006) reported that the effect of speed on the draft was less than that of the depth.

Shallow seed placement (less than $25 \mathrm{~mm}$ ) is recommended for most crops that are directly seeded
(Collins and Fowler, 1996). However, the depth of the crop roots (Table 10) will be an important factor in determining plowing depth, while the availability of time and implement width will determine the speed required to finish the work on time (Boydaf and Turgut, 2007). The results obtained from this study indicated that the depth has more effect on the draft than the forward speed; doubling the plowing depth will increase the draft by $168.3 \%$ while doubling the forward speed will only increase the draft by $21.3 \%$. Therefore, the depth of plowing should be determined based on the average root length since increasing the forward speed will not proportionally increase the draft and will improve the quality of seedbed.

Specific draft: The vertical specific draft is defined in this study as the draft per worked vertical cross sectional area. The results presented in Table 5 and Fig. 9 shows that increasing the plowing depth and/or the forward speed increased the vertical specific draft. Increasing the plowing depth from 115-230 mm (100\%) increased the vertical specific draft by $36.0,31.2,37.8$ and $32.0 \%$ for the speeds of $0.75,1.20,1.75$ and $2.30 \mathrm{~m} \mathrm{sec}^{-1}$, respectively. On the other hand, increasing the forward speed from $0.75-2.30 \mathrm{~m} \mathrm{sec}^{-1}(206.6 \%)$ increased the vertical specific draft by $45.0,46.0$ and $40.9 \%$ for the plowing depths of 115,160 and $230 \mathrm{~mm}$, respectively. On the average, doubling the plowing depth increased the vertical specific draft by $34.3 \%$ while doubling the forward speed increased the vertical specific draft by $21.3 \%$.

The horizontal specific draft is defined in this study as the draft per worked horizontal area per second. The results are presented in Table 6 and Fig. 10 show that increasing the plowing depth and/or reducing forward speed increased the horizontal specific draft. Increasing the plowing depth from 115-230 mm (100\%) increased the horizontal specific draft by 172.3, 162.9, 203.2 and $166.1 \%$ for the forward speed of $0.75,1.20,1.75$ and $2.30 \mathrm{~m} \mathrm{sec}^{-1}$, respectively. On the other hand, increasing the forward speed from $0.75-2.30 \mathrm{~m} \mathrm{sec}^{-1}$ (206.6\%) reduced the horizontal specific draft by 52.9 , 52.6 and $54.0 \%$ for the plowing depths of 115,160 and $230 \mathrm{~mm}$, respectively. On the average, doubling the plowing depth increased the horizontal specific draft by $167.1 \%$, while doubling the forward speed reduced the horizontal specific draft by $25.9 \%$

It must be noted that the vertical specific draft has much higher values than those of the horizontal specific draft, indicating that the depth of plowing has significantly more effect on the draft than the forward 
speed. Increasing the depth increased both the vertical draft and horizontal draft while increasing the forward speed increased the vertical draft and reduced the horizontal draft. This could have a significant impact on the economical tillage. Owen (1989) found the vertical force increased linearly with the plowing depth while the horizontal force increased quadratic ally with the plowing depth.

For all plowing depths, the observed rate of increase in vertical specific draft $\left(\mathrm{KN} \mathrm{m}^{-2}\right)$ when the forward speed was increased from $0.75-1.20 \mathrm{~m} \mathrm{sec}^{-1}$ was higher than the observed rate of increases in vertical specific draft when the forward speed was increased from $1.20-1.75 \mathrm{~m} \mathrm{sec}^{-1}$ and from $1.75-2.30 \mathrm{~m}$ $\mathrm{sec}^{-1}$ as shown in Table 8. However, the rate of increase in the vertical specific draft observed when the forward speed was increased from $1.20-1.75 \mathrm{~m} \mathrm{sec}^{-1}$ was lower than the rate of increase in the draft observed when the forward speed was increased from $1.75-2.30 \mathrm{~m} \mathrm{sec}^{-1}$. This would again indicate that the forward speed of $1.75 \mathrm{~m} \mathrm{sec}^{-1}$ is the optimum forward speed. For a given forward speed, the vertical specific draft increased with the increase in depth. It was, however, observed that the increase in vertical specific draft when the depth was increased from 115-160 $\mathrm{mm}$ was higher than the rate of increase in the vertical specific draft when the depth was increased from 160-230 $\mathrm{mm}$ at all forward speeds as shown in Table 9. On the other hand increasing the depth and/or the forward speed reduced the rate of increase in the horizontal specific draft as shown in Table 8 and 9. Van Muysen et al. (2000) stated that the specific draft is affected by the tool geometry.

Coefficient of pull: The coefficient of pull is defined in this study as the draft divided by the total weight of the plow and the worked soil. The weight of the worked soil was determined by multiplying the soil density by the volume of the worked soil. The volume of the worked soil was determined by multiplying the plowed depth by the width of plowed strip by the forward speed. The results presented in Table 7 and Fig. 11 show that increasing the depth of plowing increased the coefficient of pull for all forward speeds. Increasing the plowing depth from $115-230 \mathrm{~mm}(100 \%)$ increased the coefficient of pull by $84.2,65.7,65.5$ and $51.9 \%$ for the forward speeds of $0.75,1.20,1.75$ and $2.30 \mathrm{~m} \mathrm{sec}^{-1}$, respectively. On the other hand, increasing the forward speed from $0.75-2.30 \mathrm{~m} \mathrm{sec}^{-1}(206.6 \%)$ reduced the coefficient of pull by $28.9,33.3$ and $41.4 \%$ for the plowing depths of 115,160 and $230 \mathrm{~mm}$, respectively. From the results it appears that increasing the forward speed and reducing plowing depth will have significant impact on cost of tillage operation.

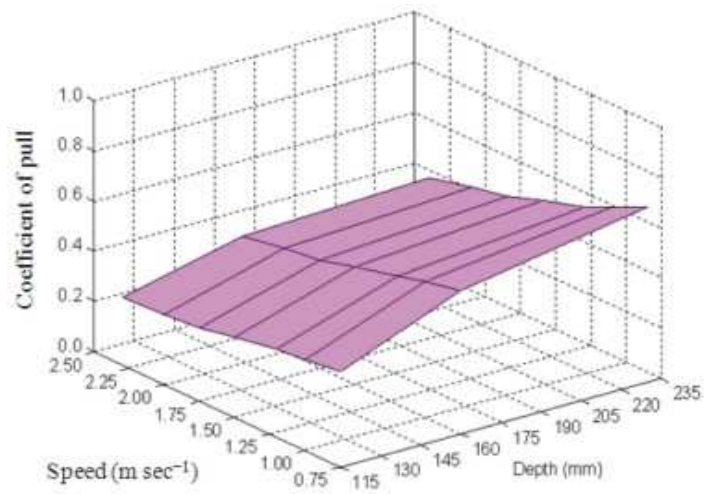

(a)

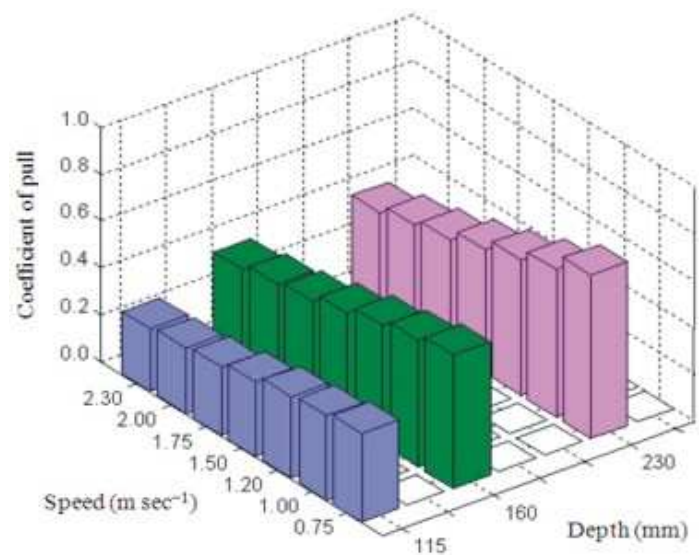

(b)

Fig. 11: Effects of plowing depth and forward speed on the coefficient of pull

\section{CONCLUSION}

The effects of plowing depth and forward speeds on draft, unit draft, vertical draft, horizontal draft and coefficient of pull were evaluated. The results indicated that increasing the plowing depth and/or the forward speed increased the draft, unit draft and vertical specific draft. Also, increasing the plowing depth increased the horizontal specific draft and the coefficient of pull, while increasing the speed decreased the horizontal specific draft and the coefficient of pull.

About $26.7 \%$ of the draft force was directed towards cutting the soil and $73.3 \%$ was consumed in pulverization of soil particles. The values of the vertical specific draft were much higher than those of the horizontal specific draft for all plowing depths and forward speeds. The plowing depth had more pronounced effect on the draft, unit draft, specific draft and coefficient of pull than the forward speed. The optimum forward speed was $1.75 \mathrm{~m} \mathrm{sec}^{-1}$. The recommended plowing depth should be based on the type of crop (depth of the root system). 
Shallow seed placement (less than $25 \mathrm{~mm}$ ) is recommended for most crops that are directly seeded. However, the depth of the crop roots to be raised is a deterministic factor of plowing depth, while the availability of time and implement width will determine the speed required to finish the study on time. The results obtained from this study indicated that the depth has more effect on the draft. Therefore, the depth of plowing should be determined based on the root length. Increasing the forward speed and reducing plowing depth will have significant impact on cost of tillage operation.

\section{ACKNOWLEDGEMENT}

The study was founded by King Saud University. The assistance provided by Engineers Mohamed Sharaf and Ibrahim Tabash and Yousef Al-Majhadi during the field study and data analysis is highly appreciated.

\section{REFEENCES}

Abbaspur-Gilandeh, Y., R. Alimardani, A. Khalilian, A. Keyhan and S.H. Sadati, 2006. Energy requirement of site-specific and conventional tillage as affected by tractor speed and soil parameters. Int. J. Agric. Biol., 8: 499-503. http://www.fspublishers.org/ijab/pastissues/IJABVOL_8_NO_4/18.pdf

Al-Suhaibani, S.A., A.A. Al-Janobi and Y.N. Al-Majhadi, 2010. Development and evaluation of tractors and tillage implements instrumentation system. Am. J. Eng. Applied Sci., 3: 363-371. http://www.scipub.org/fulltext/ajeas/ajeas32363-371.pdf

Arvidsson, J., T. Keller and K. Gustafsson, 2004. Specific draught for moldboard plough, chisel plough and disc harrow at different water contents. Soil Tillage Res., 79: 221-231. DOI: 10.1016/j.still.2004.07.010

ASAE Standards, 1985. Procedure for sprinkler distribution testing for research purposes. American Society of Agricultural Engineers.

Boydaf, M.G. and N. Turgut, 2007. Effect of tillage implements and operating speeds on soil physical properties and wheat emergence. Turk. J. Agric. For., 31: 399-412. http://journals.tubitak.gov.tr/agriculture/issues/tar07-31-6/tar-31-6-6-0703-18.pdf

Brown, N.H., M.A. Gerein and R.L. Kushwaha, 1989. Cultivator design modifications using finite element analysis. Applied Eng. Agric., 5: 148-152. http://asae.frymulti.com/abstract.asp?aid=26494\&t=1

Collins, B.A. and D.B. Fowler, 1996. Effect of soil characteristics, seeding depth, operating speed and opener design on draft forces during direct seeding. Soil Tillage Res., 39: 199-211. DOI: 10.1016/S0167-1987(96)01062-8
Finner, M.F. and R.J. Straub, 1985. Farm Machinery Fundamentals. 2nd Edn., American Publishing Co., Madison, WI., USA., pp: 354.

Gill, W.R. and G.E. Vanden Berg, 1967. Soil dynamics in tillage and traction. Agricultural Research Service. US Department of Agriculture. http://opac.cc.affrc.go.jp/alis/details.csp?LANG=E NG\&RESULT set $=$ S2 $\% 2 C S 1 \% 2 C \& R A N G E=50 \&$ RANGEst $=1 \& D B=$ all $\&$ Srt $=$ TL $\&$ TYPE $=$ T $\&$ kikan $=$ $1 \& \mathrm{ACNO}=20070214 \mathrm{~T} 00323$

Mamman, E. and K.C. Oni, 2005. Draught performance of a range of model chisel furrowers. Agric. Eng. Int. CIGR EJ., 3: 1-17. http://testdspace.library.cornell.edu/bitstream/handle/1813/1 0474/PM\%2005\%20003\%20Mamman\%20final\%2 02Dec2005.pdf? sequence $=1$

Naderloo, L., R. Alimadani, A. Akram, P. Javadikia and H.Z. Khanghah, 2009. Tillage depth and forward speed effects on draft of three primary tillage implements in clay loam soil. J. Food, Agric. Environ., 7: 382-385. http://www.worldfood.net/scientficjournal/2009/issue3/pdf/agricultur e/34.pdf

Olatunji, O.M. and R.M. Davies, 2009. Effect of weight and draught on the performance of disc plough on sandy-loam soil. Res. J. Applied Sci., Eng. Technol., $\quad 1$ 2 22-26. http://maxwellsci.com/print/rjaset/22-26.pdf

Owen, G.T., 1989. Force-depth relationships in a pedogenetically compacted clay loam soil. Applied Eng. $\quad$ Agric., 5: 185-191. http://asae.frymulti.com/abstract.asp?aid $=26501 \& \mathrm{t}=1$

Raper, R.L., 2002. The influence of implement type tillage depth and tillage timing on residue burial. Trans. Am. Soc. Agric. Biol. Eng., 45: 1281-1286. http://asae.frymulti.com/abstract.asp?aid $=11056 \& \mathrm{t}=2$

Sahu, R.K. and H. Raheman, 2006. Draught prediction of agricultural implements using reference tillage tools in sandy clay loam soil. Biosyst. Eng., 94: 275-284. DOI: 10.1016/j.biosystemseng.2006.01.015

Srivastava, A.K., 1993. Engineering Principles of Agricultural Machines. 1st Edn., American Society of Agricultural and Biological, St. Joseph, MI., pp: 601.

Taniguchi, T., J.T. Makanga, K. Ohtomo and T. Kishimoto, 1999. Draft and soil manipulation by a moldboard plow under different forward speed and body attachments. Trans. Am. Soc. Agric. Biol. $\quad$ Eng., 42: 1517-1522. http://asae.frymulti.com/abstract.asp?aid=13315\&t=1

Van Muysen, W., G. Govers, K. Van Oost and A. Van Rompaey, 2000. The effect of tillage depth, tillage speed and soil condition on chisel tillage erosivity. J. Soil Water Conserv., 55: 355-364. http://www.jswconline.org/content/55/3/355.abstract 